\title{
IMPACT OF MANAGEMENT AUTHORITY TRANSFER OF SMA/SMK FROM REgEnCY/City GovernMENT TO ProvinCIAL GoverNMENT IN WEST KALIMANTAN
}

\author{
Hamid Darmadi \\ IKIP PGRI Pontianak, Pontianak, Indonesia \\ E-mail: hamiddarmadi@gmail.com
}

\begin{abstract}
The purpose of this study is to obtain objective information and clarity regarding the impact of management authority transfer of senior high school (SMA)/vocational high school (SMK) from regency/city government to the provincial government in West Kalimantan Province. The benefit of the results theoretical and practical for teachers, school principals, education and culture services and regional governments. The population in this study were SMA/SMK teachers, SMA/SMK principals, regency/city education office and the provincial education office of West Kalimantan. This study uses direct communication techniques, direct observation techniques, and documentation techniques. The results of this study indicate that: (1) Management of SMA/SMK by the regency/city government and school activities run smoothly before the authority transfer of SMA/SMK to the Provincial Government Staffing. There is no separation between elementary school, junior school, high school and vocational school by Regency/City Education Service; (2) Management of SMA/SMK after the transfer of authority by the provincial government is obtained data and information there is a tendency for SMA/SMK to be abandoned by Regency/City Education Services because they are not responsible anymore to take care of SMA/SMK, while the Provincial Education Service which has the mandate to take care of SMA/SMK is difficult to reach schools, especially SMA/SMK far in remote areas, outermost, disadvantaged and remote areas; (3) The workload of the Head of Regency/City SMA/SMK Court MKKS after the transfer of management of SMA/SMK to the province is felt to be increasingly heavy. Because the duties of the School Supervisor that should be handled by the SMA/SMK Supervisor cannot be implemented properly due to the limited budget of the visit, the location of the SMA/SMK is too far away. Finally, the task of the School Supervisor was forced to be taken over by the Chairperson of the Regency/City MKKS. Even to the extent that the selection of selected SMA/SMK principals is conducted by the Chairperson of the MKKS.
\end{abstract}

Keywords: Senior High School; Vocational High School; Management Transfer

\section{INTRODUCTION}

It is only natural for the transfer of authority for the management of SMA/SMK from the regency/city government to the provincial government or from one institution to another. But it becomes unnatural if a school institution managed by an institution feels comfortable and comfortable handled by an institution that has long handled it. Comfortable or not comfortable, comfortable or uncomfortable if the regulations governing it should not be done, then feel comfortable and at home should be damaged for the regulation that regulates it. Likewise, the regulations that occur in the management of SMA/SMK from regency/city to province. Even though the school feels comfortable being handled by the regency/city government, but when the regulations governing it must be separated from comfort and convenience, it must be done. The government policy of issuing Law No. 23 of 2014 concerning Regional Government which requires the transfer of management of SMA/SMK from the regency/city government to the provincial government indicates that the SMA/SMK which has been handled by the regency/city government has shifted the management function by the provincial government. Implementation of Regional Autonomy as stipulated in Law Number 23 the Year 2014, legalizes the regional government to take care of all matters in their respective regions, including being responsible for the education sector. Ideologically the idea of regional autonomy is aimed at accelerating the realization of people's welfare through improved services, empowerment and community participation in managing their respective 
regions including the management of the roles and responsibilities of local government in education, and the Regional Government Affairs division. "Law 23 of 2014," he said. Law No. 23 of 2014, which relies on the ability of local resources based on efficiency, effectiveness, accountability, responsibility, and transparency, aims to create quality services. The fact is that the implementation of education that has been available so far in Indonesia. Education from kindergarten to secondary education (equivalent to SMA/SMK) is entrusted with its management to regency/city governments. In its journey, the management of education from kindergarten to secondary education (SMA/SMK) which has been managed by regencies/cities that should have high achievements and be able to compete with education with other countries has not shown positive results. Even our education (Indonesia) which used to be above average and copied by several neighboring countries turned out to be in the back position. Recognizing the delay, the central government through the Ministry of Education and Culture divides the management of education into two containers namely; the regency/city government manages the kindergarten to junior high school, while the provincial government manages vocational and high school secondary education.

In Law Number 23 of 2014 concerning Regional Government which regulates the authority to manage secondary education (SMA/SMK) and special education from the regency/city government to the provincial government, it is explained that the authority of the regional government to manage education is SMA/SMK provincial government. Regency/city governments only focus on managing equal elementary schools and equivalent junior secondary schools. With the enactment of this policy, creating new problems for regions that use the policy of regional autonomy, especially regions that have implemented free schools, it must clash with Law No. 23 of 2014 issued by the Central Government. After the enactment of Law No. 23 of 2014 for regions that have had free education programs must adjust the provincial government regulations. Local governments also find it difficult to equalize policies from the central government. The difficulty of the central government is also a problem for controlling education from each region due to the constraints of considerable distances or schools located in the interior, border borders in front of the country and remote areas. This is different from the regions whose economies are quite advanced so that they can allocate budgets and develop education that is in accordance with regional capabilities.

If studied nationally, many regencies/cities contradict the issuance of Law No. 23 of 2014 by the central government, so it is not surprising that they submitted a request to the Constitutional Court (MK) to examine the laws of the regional government regarding the management of SMA/SMK equivalent to the provincial government. As was done by the Government of Surabaya City, Blitar City, Bandar Lampung, Banten and various other regencies/cities in Indonesia.
The Government of West Kalimantan Province through the education office once made a policy of 12 years of compulsory education. The Pontianak City Government Education Unit facilitates all school operational costs and responsibilities for funding needs and has been funded by the Pontianak City Budget. Since the enactment of Law Number 23, the Year 2014 concerning regional government in lieu of Law Number 32 the Year 2004, management of SMA/SMK management has moved to the provincial government. Pontianak City Government must submit management that includes assets, human resources (HR) and finance. In terms of assets, there will be devolution of assets of regency/city SMA/SMK to the provincial government.

Based on the above conditions, Law Number 23 the Year 2014 means that the central government's policy is not in accordance with Mayor Regulation Number 15 of 2011 concerning 12-year compulsory education. Furthermore, the people of Pontianak City also tried to find a way out by issuing the policy, the regency/city government of West Kalimantan and its community elements had submitted a proposal to the Minister of Education and Culture through the Governor of West Kalimantan at that time to maintain the management of Regency/City Government Education. Implementation has an important role in the process of improving the quality of human resources. In this case, both the regency/city government and the provincial government play an equally important role in providing quality education Regarding the problem, it is only natural that the government together with elements of the community seek to realize education through various efforts to develop quality education, including through education management, curriculum enhancement, improvement of evaluation systems, improvement of educational facilities, development and provision of teaching materials, and training and recruitment of skilled teachers in their fields according to their level and level of education. Various efforts made by the government in improving the quality of education have not shown satisfactory results, and some have not often been caused by improper management, on the other hand it is also often caused by the placement of education personnel who are not in accordance with their fields of expertise, educational services and problem-solving is not by experts, so the aim of national education is to improve quality in each type and level of education has not been realized as expected. This phenomenon has implications for the emergence of problems in the management of education between the regency/city government and the provincial government. So that the problem does not cause problems that have implications for education, the solution needs to be sought because it needs to find out the root of the problem so as not to create a sustainable gap between the development of education that never ends. This is what encourages writers to find out in depth through research with a focus on the issue of "Impact of Management Authority Transfer of SMA/SMK from Regency/City Government to Provincial Government in West Kalimantan".

The problem in this study is: "What is the Impact of the Management Authority Transfer of SMA/SMK from the 
Regency/City Government to the Provincial Government in West Kalimantan?". with the sub-problems studied as follows:

1. What is the Management of SMA/SMK by the regency/city government before the transfer of authority of SMA/SMK Education to the provincial government?

2. How is the management of SMA/SMK after the transfer of authority by the provincial government?

3. What is the workload of the Head of SMA/SMK Court MKKS after the transfer of management of SMA/SMK to the province occurs?

The purpose of this study is to obtain objective information and clarity regarding the impact of management authority transfer of SMA/SMK from regency/city government to the provincial government in West Kalimantan Province. The benefits of this study differ in theoretical benefits and practical benefits, namely:

a. The academic theoretical benefits that this research can contribute to the thinking of regency/city governments, provincial governments, and the central government in considering the impact of education management to develop and improve services to the general public and educators especially in providing better education and quality.

b. The practical benefits of the results of this study are expected to contribute suggestions and thoughts to stakeholders in developing practical knowledge, especially in the field of education related to the impact of Law No. 23 of 2014 concerning Management of SMA/SMK from regency/city government to provincial government as a contribution to the development of quality human resources in realizing a quality Indonesian society both at the regency/city level and at the provincial level.

\section{Methodology}

\section{A. Research Methods}

This study uses descriptive analytical methods with the aim of knowing objective information and clarity in order to define the implementation of a planned, measurable, systematic, and structured education, both practically and theoretically, the types of data used in this study are primary data and secondary data. Primary data is obtained directly from research observations and obtained directly from other parties and informants who can be justified. While secondary data is obtained from literature studies, literature studies, and previous studies relating to the management of SMA/SMK in both the Province of West Kalimantan and in libraries at various universities, in general, are representative.

The primary and secondary data used in this study were also obtained directly from the Regency/City Education Office and the West Kalimantan Provincial Education Office relating to research and literature such as books, magazines, journals, previous research, internet, and other justifiable sources. This primary data is obtained directly by researchers through direct observation, interviews, and collecting documents from informants. The informants used in this study as primary data were informants from the Regency/City Education Office and the West Kalimantan Provincial Education Office. This data source comes from the literature in the form of books, reports, newspapers (general daily) and others related.

The data collection method used in this study was conducted by visiting the subject of the study directly by conducting interviews with informants, namely interviews with the Head of Secondary Education and the Head of the Infrastructure Section for Secondary Education in several regencies and the West Kalimantan Provincial Education Service in Indonesia. In addition to conducting interviews with the Regional Head Office and the Head of the Education Office, it was also conducted with several principals and SMA/SMK teachers as the main actors in Regency/City Education Offices spread across various Regencies/Cities in West Kalimantan Province.

Analysis of the data in this study was carried out by nonstatistical qualitative analysis by describing data obtained with words in narratives, images, tables, etc. related to qualitative analysis in the form of categories to draw conclusions. Qualitative data analysis is done after the data has been processed, analyzed and compared with theories which are then evaluated to find out the truth. The presentation of data in this study uses narrative descriptions and describes the background and implementation of Law Number 23 of 2014 concerning the transfer of management of SMA/SMK from the regency/city government to the provincial government.

The results of the data analysis are drawn conclusions to answer the problems and sub-problems that have been formulated with qualitative data qualifications. Qualitative data analysis is carried out as a running process as follows: (a) Record what is produced from the field, then provide the code so that the data source can still be tracked; (b) Collect, sort, group, summarize and index the data that has been collected; (c) Categorize the data so that the data has meaning, find and find patterns and relationships and make general findings that have relevance to the research problem that is raised from the object/subject of research.

\section{B. Form of Research}

This study uses descriptive analytical research. The purpose of analytic descriptive research in addition to explaining the main problems studied, this study also analyzes and interprets the data to find an answer to the problems under study. The data obtained is then not written in statistical form, but in a richer qualitative descriptive form: "facts, data, narration, images, illustrations and frequencies", to describe the background of the implementation of Law No. 23 of 2014 concerning the management of equivalent SMA/SMK under the regency/city administration and the West Kalimantan Provincial Education Office.

Descriptive research forms are distinguished in purpose and method. Objective refers to the expansion of science, called basic research, to solve problems and to get benefits 
for many people which are generally referred to as applied research with survey forms. While the Method is done by describing an object/subject of research clearly and systematically with the aim of predicting the symptoms that arise due to data obtained in the field in this study.

\section{Research Object/Subject}

The objects/subjects in this study are SMA/SMK teachers, principals, and elements of the regency/city education office, elements of the provincial education office, which are defined as objects/subjects of research.

\section{Data Collection Techniques and Tools}

\section{a. Direct Communication Techniques}

Direct communication techniques use interview guides. Interviews in this study were conducted with the Head of Regency/City and Provincial Education Services, Principals, teachers and other relevant officials. The purpose of the interview is to explore the right data and information from trusted sources from the Head of the Regency/City Education Office and the Provincial Education Office.

\section{b. Direct Observation Technique}

Direct observation techniques use observation guidance as a data collection tool. Observations were made to the School, the Head of the Regency/City Education Office and the Education Office of West Kalimantan Province which was the object of research. The purpose of observation is to observe, by making a systematic record consisting of several elements that appear in the phenomenon in the object of research. The results of the observations are formulated in the form of systematic reports in accordance with applicable rules (Nawawi and Martini, 2008).

1) Documentation Technique

The documentation technique uses data collection tools in the form of documents, recordings, videos, photos of activities that have an impact on the implementation of SMA/SMK management by the regency/city government to the provincial government. Documentation studies are intended to examine various types of documents relating to the impact of the management of education of SMA/SMK by the regency/city government to the provincial government of West Kalimantan.

The documents used in this data collection are divided into two, namely: Primary documents Secondary documents. Primary documents are documents written by people who directly experience an event, such as writing an autobiography. Secondary documents are documents written based on other people's reports/stories, for example, such as someone's biography. The steps taken in the data analysis process in this study are carried out in the form of (1) Data reduction; (2) Data coding; (3) Linking themes as outlined in narrative form; and (4) Data interpretation.
2) Data Analysis Technique

Data analysis techniques in this study were carried out after the data collection process was completed. Data Analysis Techniques carried out in this study there are several cases, phenomena, and events carried out repeatedly, especially for objects/subjects that show doubts and lack of certainty of data that has been obtained. The purpose of data analysis is to identify the social patterns of symptoms or social phenomena, and the events studied.

a. Checking Data Completeness

This stage is done immediately after the data is collected. The researcher makes a checklist to ascertain whether all data has been collected. Note that there are no perfect datasets or field records. There are always flaws and gaps after the data is collected. However, it is important for researchers to justify that the data collected is suitable for analysis. Justification is certainly based on the design of initial research on what data is needed to answer research questions. In short, if the data is sufficient, it can be considered complete.

b. Checking Data Quality

This stage is done by observing or reading repeatedly whether the answers of the informants as expected by the researcher, in the sense that all the columns are filled or all questions are answered satisfactorily. Data quality checks are carried out to determine how much data is lost and need to do additional data searches.

3) Clustering Data

After the researcher confirms that the data collected is sufficient and is considered quality, the next step is to create a cluster. This stage is very important because it affects the systematic determination of research. Without grouping, researchers will confuse themselves and potentially get lost in the complexity of the data they have. Clustering can also be called grouping. In essence, making a data classification. Data classification must refer to data relevance and quality. The researcher ensures that each research question is classified.

4) Perform Data Analysis

After data is clearly classified, data analysis can be done to find patterns. While qualitative research uses coding. Both can be done manually or with the help of computer software. (a) Qualitative data analysis techniques in conducting qualitative data analysis techniques, researchers collected data from various sources using various data collection techniques (triangulation). Data collection is carried out continuously, so as to produce various data. The data obtained is basically qualitative data. Qualitative data analysis is done by coding. The coding process involves determining concepts or variables that precede. Coding serves to facilitate researchers to make valid and systematic conclusions. In short, coding is the process of categorizing qualitative data 
so that it can be easily measured or understood. (b) Descriptive data analysis techniques is a way of checking the status of a group of people, an object, condition, system of thought or also current events. This type of qualitative research method seeks to explain social phenomena at certain times. Qualitative research methods are divided into several types, namely based on the criteria of differentiation between functions and other final approaches.

\section{RESULTS AND DISCUSSION}

Based on data collected by questionnaires to SMA/SMK teachers, the results of interviews with MKKS Chairmen, SMA/SMK Principals, Head of Regency/City Education Office, elements related to Regency/City Education Service Officers, elements related to Provincial Education Office and Head of Provincial Education Office West Kalimantan obtained data and information that: impact of management authority transfer of SMA/SMK from regency/city government to provincial government in West Kalimantan Province ". Can be formulated as follows:

\section{First: Administrative Data Management of SMA/SMK}

1. The results of the study indicate that the preparation process and regulations carried out by the Provincial Education Service in the implementation of the transfer of management authority of SMA/SMK in the Province of West Kalimantan have taken place. Steps that have been taken such as coordination, socialization, and synergy carried out with school authorities and with other relevant parties are carried out based on applicable rules and regulations. But still need improvement, this increase is done to maximize the transfer of SMA/SMK authorities.

2. The preparation process carried out by the Educational Resources Office of West Kalimantan Province has already taken place. Human resource preparation that directly handles activities as representatives of the Provincial Education Office in the regency/city is generally inadequate so it is not uncommon for the Regency Education Office to help take over functions such as PORSENI, Olympic competitions, and various other activities. handled by the Regency/City Education Office.

3. As an education management transfer sector, implementers already have anthropicism both in work, ideas and ideas have also been appointed to be applied to the employees themselves in carrying out their duties. Unfortunately, the staff of the Provincial Education Office has not been able to make significant methods and regulations that can create employee work comfort and the convenience of teachers and principals in regencies/cities far from the provincial capital.

Second: Data from the Provincial Education Service Authority

4. The West Kalimantan Provincial Education Service Authority is shocking, there are 5,617 ASNs who have switched status to civil servants from the government of the Province of West Kalimantan. While the movable assets are 644 parcels of land, 18,723 units of equipment and machinery, 1,632 buildings and buildings, 262 units of roads, irrigation and networks, 75,722 units of fixed assets are running and 24 construction units are under construction. While civil servants from West Kalimantan Province.

5. Governments that are PNS Ministry of Education are 24 people. While facilities and infrastructure were transferred, namely three plots of land, 1,034 units, 63 buildings and buildings, and 6 other fixed assets.

6. The Head of the West Kalimantan Education Office at that time (Alexius Akim) said there were 300 SMA/SMK who switched statuses where the management was under the Government of the Province of West Kalimantan.

7. The management formula is available. Including echelon IV officials in the Regency/City Education Office that manages this assistance task. This officer is the spearhead to continue what is done by the province to the education unit. Unfortunately, when this research was done it was not found/there is no regency/city Education Agency officer who manages aid assignments

8. The transfer of management of SMA/SMK does indeed have implications for shifting teacher status from regency/city government officials to provincial government employees. In addition, it also has an impact on changes in organizational structure and work procedures. On the one hand, management transfers indeed provide additional authority to the West Kalimantan Provincial Government in managing SMA/SMK. But at the same time, management transfers also put an additional burden on the provincial government.

9. Additional expenses are borne by the provincial government related to the budget. In terms of teacher salaries, the provincial government does get general allocation funds. Management of SMA/SMK does not only cover the management of teaching staff. Transfer of education management also includes school infrastructure management, school construction, and students.

10. Transfer of management of SMA/SMK from regency/city to province which has been implemented since January 2017, as mandated by Law No. 32/2014 concerning Regional Government implies that several regencies/cities react to the refusal of the management of SMA/SMK to the province but still must submit to the constitutional mandates and regulations that apply in this country.

11. The provincial government has never asked for the allocation of management of SMA/SMK education to the province, but the mandate regulation of Law No. 32/2014 concerning regional government implies that the regency/city government must submit the management of SMA/SMK education to the provincial government. The provincial government is implementing regulations that have been regulated by the law. 


\section{Third: Data from the Principal and Regency/City Education} Service Authority

12. The reluctance of some regencies/cities to release the management power of SMA/SMK to the provincial government is due to several interests. The regency/city government considers SMA/SMK as part of the implementation of cheap (free) education for its citizens because the education subsidy budget has been allocated for years for underprivileged students who will take senior secondary education in their area.

13. The transfer of management of SMA/SMK authority adheres to the basic principles of regional autonomy, regional autonomy requires authorities to regency/city to carry out facilitation services for Secondary Education (SMA/SMK) in accordance with the budgetary capacity and regional vision.

14. The successful management of SMK at the regency/city level has the potential to be 'disrupted' by the management of education to the province. The provincial government, in this case, the Ministry of Education is considered untested in carrying out the stages, work programs and actualization of technology competencybased vocational education.

15. The transfer of authority for management of upper secondary education to the province reduces the education budget allocation from the central government to the regency/city government. So that the number of general allocation funds and special allocation funds in the education sector channeled by the central government will be drastically reduced. Logically the budget is a loss for the regency/city government.

16. For the community, the transfer of management of SMA/SMK to the province raises concerns. Among these concerns related to subsidies for the costs of SMA/SMK so far are borne by the regency/city government. If the budget allocation from the provincial government is insufficient, the burden of education costs will be delegated to the parents of students, so the tuition fees will swell to students/parents.

17. Positive things that arise from the management of SMA/SMK are mapping and structuring the quality of high school (SMA/SMK) education. The provincial government is expected to implement a teacher equalization program so that there is no accumulation of teachers in the city. The provincial government can provide special allowances for teachers who work in rural areas, borders and remote, outermost and disadvantaged areas.

18. The transfer of authority in the management of SMA/SMK in national education schemes actually also presents opportunities for cooperation in cross-sectoral development.

19. Regency/city SMK. Provincial governments have more opportunities and authority to implement 'competitive learning' programs from vocational education.

20. The purpose of transferring management of authority makes it easier for the provincial government to prioritize secondary education, and to complete the 12year compulsory education program.

21. Some regency/city areas that previously excluded education from primary to SMA/SMK are now no longer free. In fact, it is relatively expensive to educate students to pay for education.

22. The transfer of management of SMA/SMK to the provincial government is not a guarantee of education that comes out of the trap of "lagging behind" increasingly professional power and management.

23. If the word was told to choose from 487 teachers who were enlisted and 67 SMA/SMK principals interviewed only one person who chose to stay in school was managed by the provincial government, the rest both teachers and Principals re-elected to be managed by regencies/cities.

Fourth: Data from the Head of Regency/City SMA/SMK Court MKKS

24. Administratively the distance between the location of the school and the Provincial Education Service Supervisor is the main role in carrying out tasks even though documents can sometimes be collected through WA but are not effective.

25. There is no Branch Office of Education in the regency/city, making communication sometimes hampered, especially for teachers who do not have an internet network so they miss important information and must immediately be known.

26. The existence of MKKS whose function is not clear as an Education Service Branch or only as information connector. Because for the past two years MKKS has been empowered to coordinate anything related to school data collection, but on the other hand there are no operational funds for MKKS in carrying out their duties.

27. All student activities carried out by regency/city have no funding at all. Regency service there is also no funding for that, all is charged to the school, while the source of BOS funds is not allowed for funding.

28. Because the extent of the coaching area is a little difficult for the guidance and monitoring of schools, including the limitation of guidance from school supervisors that is far from sufficient.

29. Lack of teaching staff because the Regional Coordination Teachers (GKD) appointed by the Bupati and placed in SMA/SMK have mostly been transferred to elementary and junior high schools. On the other hand, the school may not appoint honorary teachers to meet these shortcomings.

30. Since SMA/SMK has been transferred to the province, there is no income allowance (Tamsil) other than the monthly salary and other benefits. Previous SMA/SMK have received Workload Allowances (TBK), the amount of which is in accordance with the capacity of the regency/city, now there are no more. 


\section{IV.CONCLUSIONS AND SUGGESTIONS}

\section{A. Conclusions}

Based on the analysis of the data obtained from the field, it can be concluded in general that: the impact of the management authority transfer of SMA/SMK from the regency/city government to the provincial government in West Kalimantan Province has not been as expected. Especially can be summarized as follows: (a) Management of SMA/SMK by the regency/city government and school activities run smoothly before the transfer of authority of SMA/SMK to the Provincial Government Staffing. There is no separation between elementary, junior school, high school, and vocational school by the Regency/City Education Office; (b) Management of SMA/SMK after the transfer of authority by the provincial government was obtained data and information that there was a tendency for SMA/SMK to be left behind by the Regency/City Education Service because they were irresponsible to take care of SMA/SMK, while the Provincial Education Service received for taking care of SMA/SMK is difficult to reach schools especially SMA/SMK which are far in the remote, outermost, remote and remote areas; (c)The workload of the Head of Regency/City SMA/SMK Court MKKS after the transfer of SMA/SMK education to the province is felt to be increasingly heavy. Because the duties of the School Supervisor that should be handled by the SMA/SMK Supervisor cannot be implemented properly due to the limited budget of the visit, the location of the SMA/SMK is too far away. Finally, the task of the School Supervisor was forced to be taken over by the Chairperson of the Regency/City MKKS. Even to the extent that the selection of selected SMA/SMK principals is conducted by the Chairperson of the MKKS.

\section{B. Suggestions}

a. The West Kalimantan Provincial Office is expected to improve performance, especially regarding P3D.

b. There needs to be an evaluation program that aims to find out the obstacles that occur during the P3D process and can provide the best solutions/alternatives in overcoming these obstacles.

c. The West Kalimantan Provincial Education Office in this case specifically the Secondary Education Sector should be able to take steps that make it easier for the West Kalimantan Provincial Education Office itself as the main actor in the process of transferring authority and all relevant agencies.

d. The need to establish a communication forum that can be used as a forum to discuss any matters relating to the preparation of this authority.

e. Regular visit activities are needed in every school throughout the Province of West Kalimantan so that areas far from the center do not experience delays and cannot be separated from the reach of the center so that the maximization of education expected from this activity can be realized. f. The transfer of management of SMA/SMK to the province must still be supported by active participation from the regency/city government and all education stakeholders. Support in the form of local policies, budget support, and alignment of education missions. But the responsibility of senior secondary education is a shared responsibility between the government and the community.

\section{REFERENCES}

Articles. (2016). Plus Minus Transfer Management of SMA/SMK Transfer management of Vocational School of High School to Regional District.

Bapenas. (2016). Library Bappenas.go.id/lontar/file? digital file / 166560- Manage high school / vocational school by province. Jakarta-Kompas.

Blitar Major Sues. Regional Government Law: Standing Management of High Schools and Vocational Schools, Major of Blitar Sues Regional Government Law.

Damayanti. Prospective Policy Analysis of Transfer Management of SMA/SMK to the provincial government is considered inappropriate. Journal of Airlangga University. www.journal.unair.ac.id/ download-fullpapers-kmp1beaefc49ffull.pdf.

Darmadi, Hamid. (2018). Implications of Managing High School/Vocational Education from Regency Government to Provincial Government in Bengkayang Regency.

Education Board of West Kalimantan Province Kapuas Edukasi. (2018). Sangkarut Pumgutan, School Aid Donation: High School Education Management Transfer Policy.

Highlighting the Transfer of Management of High Schools/Vocational Schools. (2017). It is true that this also signifies the management policy for SMA/SMK transfer.

Minister of Education and Culture. (2016). Transfer Management of High Schools/Vocational Schools Mandate of Regional Government Law. https://republika .co.id

Prasetyo. (2017). Law on Implementation of Sunan Ampel Surabaya UIN is adopted. uinsby.ac.id/21977/51/Imam Prasetyo. E04213035.

Tempo. (2017). MK Decides Management of High School Under the Provincial Government. https://nasional.tempo.co Nasional Jul 20, 2017.

West Java Education Agency. (2015). Transition of Senior High School/Prepared Mature Vocational School. jabarprov.go.id/index/Transition_Tata_Manage_SMA_ SMK

West Java Education Agency. (2016). The Impact of Management of High Schools/Vocational Schools, the 2017 Budget Education Department of West Java along with the transfer of management of SMA/SMK to the Provinces. 